\title{
REFORMULASI KETATANEGARAN INDONESIA
}

\author{
Zulkarnain \\ Program Studi Pendidikan Sejarah \\ Fakultas Ilmu Sosial, Universitas Negeri Yogyakarta
}

\begin{abstract}
Abstrak
Keinginan politik untuk melakukan perubahan atau amandemen UUD 1945 di era reformasi dilatarbelakangi oleh -pengalaman sejarah masa lalu, baik masa Orde Lama (1959-1966) maupun pada masa Orde Baru (1966-1998). Bila kita kaji secara detail dan mendalam, dapat dikatakan bahwa UUD 1945 memang dibuat dalam keadaan tergesagesa, sehingga mengandung segi-segi kelemahan, yang memungkinkan munculnya pemerintahan yang diktator. Konstitusi ketatanegaraan Indonesia sebelum amandemen memberikan titik berat kekuasaan kepada Presiden. Majelis Permusyawaratan Rakyat, meskipun disebut sebagai pelaksana kedaulatan rakyat dan penjelmaan seluruh rakyat, dalam kenyataannya susunan dan kedudukannya sepenuhnya di bawah kendali presiden.

Keinginan untuk menata ulang kedudukan lembaga-lembaga negara agar tercipta check and balances juga terasa begitu kuatnya. Demikian pula keinginan untuk memperjuangkan tegaknya hukum dan pengakuan serta perlindungan terhadap hak asasi manusia. Keinginan untuk memberikan perhatian yang lebih besar kepada daerahdaerah juga demikian menguat, sehingga kewenangan-kewenangan Pemerintah Daerah juga perlu diperkuat untuk mencegah terjadinya disintegrasi Bangsa.
\end{abstract}

Kata Kunci: Reformulasi, Tatanegara, Indonesia.

\section{Pendahuluan}


Pada masa pemerintahan Orde Baru selama 32 tahun, rakyat tidak menyadari bahwa negara sedang menuju kepada kebangkrutan. Rakyat terpesona dengan angka-angka statistik yang menunjukkan adanya pertumbuhan ekonomi nasional yang tinggi, tanpa menyadari apa yang sebenarnya sedang terjadi. Pemerintahan yang bergaya militereristik telah membungkam aspirasi nasional dan protes-protes sosial yang selama itu muncul. Berbagai krisis muncul yang menambah beratnya beban republik. Krisis moral, pendidikan, politik, keagamaan, dan ekonomi semakin memperburuk citra RI di mata internasional. Bahkan Indonesia mendapat predikat sebagai negara paling korup di dunia. Namun, betapa tidak, korupsi, kolusi, nepotisme (KKN) terjadi hampir di seluruh instansi, ekonomi kerakyatan terabaikan, utang luar negeri semakin menggunung, dukungan rakyat semakin berkurang, sehingga melemahkan legitimasi pemerintah di mata rakyat. Dampaknya ketika terjadi krisis moneter internasional pada akhir tahun 1997, ekonomi nasional tidak mampu menahan jatuhnya nilai rupiah terhadap dolar Amerika. Nilai tukar rupiah terus merosot drastis, dan bahkan menyentuh angka di atas Rp 15.000 per dollar AS. Situasi krisis yang memuncak inilah yang menyebabkan hilangnya kepercayaan rakyat terhadap pemerintah.

Dalam kondisi yang serba buruk ini, aksi protes mahasiswa dan masyarakat dalam wujud demonstrasi terjadi di mana-mana, baik di Jawa maupun di luar Jawa. Demonstrasi ini menuntut beberapa hal sebagai berikut yakni, turunnya pemerintahan Soeharto, bubarkan Partai Golkar, diselenggarakannya pemilu dan Reformasi total. Karena situasi yang sudah serba sulit, akhirnya pada tanggal 21 Mei 1998 Presiden Soeharto mengembalikan mandat kepada MPR dan menyatakan diri berhenti dari jabatan presiden. MPR kemudian menetapkan B.J. Habibie sebagai presiden RI menggantikan Soeharto.

Presiden Habibie kemudian dilantik di Istana Merdeka pada tanggal itu juga di bawah sumpah jabatan. Pengunduran diri Presiden Soeharto dari jabatannya ini menandai berakhirnya pemerintahan Orde Baru yang berkuasa selama hampir 32 tahun. Pemerintahan kemudian digantikan oleh B.J. Habibie yang memerintah tanpa wakil dan 
membentuk kabinet yang diberi nama Kabinet Reformasi Pembangunan yang salah satu programnya adalah menyelenggarakan pemilu tahun 1999. Terpilihnya wakil rakyat yang duduk di legeslatif melalui pemilu yang demokratis, mendorong untuk melakukan pembenahan dalam sistim ketanegaraan kita.

\section{A. Sistem Ketatanegaraan}

Keinginan politik untuk melakukan perubahan atau amandemen UUD 1945 di era reformasi dilatarbelakangi oleh -pengalaman politik masa lalu, baik masa Orde Lama (1959-1966) maupun pada masa Orde Baru (1966-1998). Bila kita kaji secara detail dan mendalam, dapat dikatakan bahwa UUD 1945 memang dibuat dalam keadaan tergesa-gesa, sehingga mengandung segi-segi kelemahan, yang memungkinkan munculnya pemerintahan yang diktator. Konstitusi ketatanegaraan Indonesia sebelum amandemen memberikan titik berat kekuasaan kepada Presiden. Majelis Permusyawaratan Rakyat, meskipun disebut sebagai pelaksana kedaulatan rakyat dan penjelmaan seluruh rakyat, dalam kenyataannya susunan dan kedudukannya sepenuhnya di bawah kendali presiden.
Presiden Soekarno bahkan mengangkat seluruh anggota MPR tanpa proses Pemilu. Presiden Soeharto telah merekayasa undang-undang susunan dan kedudukan MPR, sehingga majelis itu tidak berdaya dalam mengawasi Presiden, dan bahkan tidak dapat melaksanakan tugas dan kewenangannya secara optimal. UUD 1945 juga mengandung ketidakjelasan mengenai batas periode masa jabatan Presiden. MPRS pernah mengangkat Presiden Soekarno sebagai presiden seumur hidup. MPR Orde Baru berkalikali mengangkat Presiden Soeharto, sampai akhirnya, atas desakan berbagai pihak, menyatakan berhenti di era awal reformasi, tanggal 21 Mei 1998. Keinginan untuk menghindari kediktatoran, baik terbuka maupun terselubung, dan membangun pemerintahan yang demokratis, menjadi latar belakang yang penting yang mendorong proses perubahan UUD 1945 pada era reformasi.

Keinginan untuk menata ulang kedudukan lembaga-lembaga negara agar tercipta check and balances juga terasa begitu kuatnya. Demikian pula keinginan untuk memperjuangkan tegaknya hukum dan pengakuan serta perlindungan terhadap hak asasi 
manusia. Keinginan untuk memberikan perhatian yang lebih besar kepada daerah-daerah juga demikian menguat, sehingga kewenangan-kewenangan Pemerintah Daerah juga perlu diperkuat untuk mencegah terjadinya disintegrasi. Pada akhirnya, keinginan yang teguh untuk membangun kesejahteraan rakyat, yang telah lama menjadi harapan dan impian, terasa demikian menguat pada era reformasi. Itulah, antara lain, latar belakang keinginan dan aspirasi yang mengiringi perubahan Undang-Undang Dasar 1945 (Ihza Mahendra, 2006).

Perubahan mendasar terhadap konstitusi kenegaraan Republik Indonesia sudah dilakukan sebanyak empat kali. Perubahan Pertama dimulai pada tahun 1999 sampai ke Perubahan Keempat pada tahun 2002. Perubahanperubahan itu meliputi materi dan substansi dari materi itu sendiri. Perubahan-perubahan mendasar yang terjadi pasca-amandemen membawa konsekuensi logis terhadap struktur dan mekanisme dalam sistem Ketatanegaraan Republik Indonesia.

Pokok-pokok pikiran baru yang diadopsikan ke dalam kerangka UUD 1945 itu di antaranya adalah: a) penegasan dianutnya cita demokrasi dan nomokrasi; (b) pemisahan kekuasaan dan prinsip checks and balances; (c) pemurnian sistem pemerintah presidensial; dan (d) penguatan cita persatuan dan keragaman dalam wadah Negara Kesatuan Republik Indonesia (Jimly Asshiddiqie, 2003).

\section{B. Perubahan Konstitusi Pada Masa Reformasi.}

Perubahan mendasar yang terjadi dalam konstitusi kita pascaperubahan/amandemen UUD 1945 adalah sebagai berikut.

1. Negara Demokrasi

Sistem Ketatanegaraan Indonesia hasil amandemen dengan tegas menyatakan bahwa Indonesia adalah negara Demokrasi dengan kedaulatan tertinggi berada di tangan rakyat. Kedaulatan rakyat diselenggarakan secara langsung melalui sistem perwakilan yang diimplementasikan dalam tiga cabang kekuasaan yakni. Majelis Permusyawaratan Rakyat (terdiri dari Dewan Perwakilan Rakyat dan Dewan Perwakilan Daerah); presiden dan wakil presiden; dan kekuasaan Kehakiman (yang terdiri atas Mahkamah Konstitusi dan Mahkamah Agung). Dalam menentukan kebijakan pokok dan pengaturan hukum berupa Undang-Undang Dasar dan Undang- 
Undang (fungsi kontrol) terhadap jalannya pemerintahan disalurkan melalui lembaga perwakilan, yakni: Majelis Permusyawaratan Rakyat, Dewan Perwakilan Rakyat, dan Dewan Perwakilan Daerah. Demikian halnya dengan kedaulatan rakyat di daerah, kontrol terhadap pemerintahan disalurkan melalui sistem perwakilan, yaitu melalui Dewan Perwakilan Rakyat Daerah. Penyaluran kedaulatan rakyat secara langsung (direct democracy) dilakukan melalui pemilihan umum untuk memlih anggota lembaga perwakilan dan memilih Presiden dan Wakil Presiden.

\section{Negara Hukum}

Selain sebagai negara demokrasi, dalam Konstitusi hasil amendemen ditegaskan bahwa negara Indonesia juga sebagai Negara Hukum (Rechtstaat), walaupun faktanya Indonesia sudah mengarah ke Negara Kekuasaan (Machtstaat), hukum yang seharusnya menjadi panglima dan berada di garda terdepan dalam memperjuangkan nilai-nilai kebenaran masih sebatas harapan yang jauh dari kenyataan. Salah satu contoh yang paling sederhana adalah kasus BLBI, Bank Century, kasus pajak, kasus M. Nazarudin, dan masih banyak kasus besar lainnya, baik di lembaga eksekutif maupun legislatif yang masih menyisahkan masalah hukum. Sementara kasus Nenek Mina yang hanya mencuri kakao untuk dijadikan pembibitan, langsung di proses oleh aparat hukum. Dalam kehidupan berbangsa dan bernegara, Hukum harus menjadi Panglima dan penentu segalanya sesuai dengan prinsip nomokrasi (nomocracy) dan doktrin 'the Rule of Law, and not of Man'. Dalam kerangka 'the rule of Law' tersebut, diyakini adanya pengakuan bahwa hukum itu mempunyai kedudukan tertinggi (supremacy of law), adanya persamaan dalam hukum dan pemerintah (equality before the law), dan berlakunya asas legalitas dalam segala bentuknya dalam kenyataan praktiek (due process of law) (Jimly Asshiddiqie, 2003).

Untuk mengatasi kekurangan itulah, dalam perubahan ketiga UUD 1945, ide negara hukum (rechtstaat atau the rule of law) itu diadopsi secara tegas ke dalam rumusan pasal UUD, yaitu Pasal 1 ayat (3) tersebut 
di atas. Sementara itu, ketentuan mengenai prinsip kedaulatan rakyat terdapat dalam pembukaan dan juga pada Pasal 1 ayat (2). Cita-cita kedaulatan tergambar dalam pembukaan UUD 1945, terutama dalam rumusan alinea IV tentang dasar negara yang kemudian dikenal dengan sebutan Pancasila. Dalam alinea ini, cita-cita kerakyatan dirumuskan secara jelas sebagai "Kerakyatan yang dipimpin oleh hikmah kebijaksanaan dalam permusyawaratan/perwakilan."

Sedangkan dalam rumusan Pasal 1 ayat (2), semangat kerakyatan itu ditegaskan dalam ketentuan yang menegaskan bahwa "kedaulatan berada di tangan rakyat dan dilaksanakan menurut UndangUndang Dasar."

\section{Pemisahan Kekuasaan}

Prinsip kedaulatan yang berasal dari rakyat tersebut di atas selama ini hanya diwujudkan dalam Majelis Permusyawaratan Rakyat yang merupakan penjelmaan seluruh rakyat, pelaku sepenuhnya kedaulatan rakyat, dan yang diakui sebagai lembaga tertinggi negara dengan kekuasaan yang tidak terbatas. Dari Majelis inilah kekuasaan rakyat itu dibagi-bagikan secara vertikal ke dalam lembagalembaga tinggi negara yang berada di bawahnya. Karena itu, prinsip yang dianut disebut sebagai prinsip pembagian kekuasaan (distribution of power). Akan tetapi, dalam Undang-Undang dasar hasil perubahan, prinsip kedaulatan rakyat tersebut dibagikan secara horizontal dengan cara memisahkannya menjadi kekuasaan-kekuasaan yang dinisbatkan sebagai fungsi lembagalembaga negara yang sederajat dan saling mengendalikan satu sama lain berdasarkan prinsip 'checks and balaces'. Cabang kekuasaan legislatif tetap berada di Majelis Permusyawaratan Rakyat, tetapi majelis ini terdiri dari dua lembaga perwakilan yang sederajat dengan lembaga negara lainnya. Untuk melengkapi pelaksanaan tugas-tugas pengawasan, di samping lembaga legislatif dibentuk pula Badan Pemeriksa Keuangan.

Cabang kekuasaan eksekutif berada di tangan Presiden dan Wakil Presiden. Untuk memberikan nasihat dan saran kepada Presiden dan Wakil Presiden, dibentuk pula Dewan 
Pertimbangan Presiden

(Wantimpres). Sedangkan cabang kekuasaan kehakiman dipegang oleh Mahkamah Agung dan Mahkamah Konstitusi. Majelis Permusyawaratan Rakyat tetap merupakan rumah penjelmaan seluruh rakyat yang strukturnya dikembangkan dalam dua kamar, yaitu Dewan Perwakilan Rakyat dan Dewan Perwakilan Rakyat Daerah. Oleh karena itu, prinsip perwakilan daerah dalam Dewan Perwakilan Rakyat Daerah harus dibedakan hakikatnya dari prinsip perwakilan rakyat dalam Dewan Perwakilan Rakyat. Perubahan pasal pasal dalam konstitusi itu untuk memastikan tafsir berkenaan dengan terjadinya pergeseran MPR dari kedudukannya sebagai lembaga tertinggi menjadi lembaga yang sederajat dengan Presiden berdasarkan pemisahan kekuasaan dan prinsip 'check and balances'.

\section{Format Trikameral}

Dalam konstitusi hasil amandemen, kita mengenal format tiga kamar (trikameral) yang meliputi tiga lembaga, yakni Majelis Permusyawaratan Rakyat (MPR),
Dewan Perwakilan Rakyat (DPR), dan Dewan Perwakilan Daerah (DPD).

Setelah amandemen keempat UUD 1945, keberadaan MPR yang sebelumnya disebut sebagai lembaga tertinggi negara, bila dilihat dari peran dan fungsinya telah mengalami perubahan yang sangat mendasar, akan tetapi keberadaannya tetap ada sehingga sistem yang kita anut tidak dapat disebut lagi sistem bikameral ataupun satu kamar, melainkan sistem tiga kamar (trikameral). Perubahan-perubahan mendasar dalam kerangka struktur parlemen Indonesia itu mengenai hal-hal sebagai berikut : Susunan keanggotaan MPR berubah secara struktural karena dihapuskannya keberadaan Utusan Golongan yang mencerminkan prinsip perwakilan fungsional (functional representation) dari unsur keanggotaan MPR. Dengan demikian, anggota MPR hanya terdiri atas anggota Dewan Perwakilan Rakyat (DPR) yang mencerminkan prinsip perwakilan politik (political representation) dan anggota Dewan Perwakilan Daerah (DPD) yang mencerminkan prinsip 
perwakilan daerah (regional representatif). Fungsi MPR mengalami perubahan mendasar (perubahan fungsional). Majelis ini tidak lagi berfungsi sebagai 'supreme body' yang memiliki kewenangan tertinggi dan tanpa kontrol, dan karena itu kewenangannya pun mengalami perubahan-perubahan mendasar. Kewenangan MPR berubah menjadi: (a) menetapkan Undang-Undang Dasar dan/atau Perubahan UUD; (b) melantik Presiden dan Wakil Presiden; (c) memberhentikan Presiden dan/atau Wakil Presiden; serta (d) menetapkan Presiden dan/atau Wakil Presiden pengganti sampai terpilihnya Presiden dan/atau Wakil Presiden sebagaimana mestinya, dan pertanggungjawaban Presiden tidak lagi dilakukan kepada Majelis Permusyawaratan Rakyat, tetapi langsung kepada rakyat.

Selain perubahan terhadap kelembagaan MPR, perubahan juga terjadi pada lembaga DPR.

Berdasarkan ketentuan UUD 1945 Perubahanan Keempat, fungsi legislatif berpusat di tangan Dewan Perwakilan Rakyat. Hal ini jelas terlihat dalam rumusan Pasal 20 ayat
(1) yang menyatakan, "Dewan Perwakilan Rakyat memegang kekuasaan membentuk UndangUndang." Selanjutnya dinyatakan, "setiap rancangan Undang-Undang dibahas oleh DPR dan Presiden untuk mendapat persetujuan bersama (ayat 2). Jika Rancangan UndangUndang itu tidak mendapat persetujuan bersama, Rancangan Undang-Undang itu tidak boleh diajukan lagi dalam persidangan DPR masa itu" (ayat 3). Kemudian dinyatakan pula "Presiden mengesahkan rancangan UndangUndang yang telah disetujui bersama untuk menjadi Undang-Undang" (ayat 4), dan "dalam hal rancangan Undang-Undang yang telah disetujui bersama tersebut tidak disahkan oleh Presiden dalam waktu tigapuluh hari semenjak rancangan UndangUndang tersebut disetujui, rancangan Undang-Undang tersebut sah menjadi Undang-Undang dan wajib diundangkan" (ayat 5).

Selain Peran dan fungsi Kelembagaan MPR dan DPR,dalam amandemen konstitusi kita mengenal lembaga Dewan Perwakilan Daerah (DPD). Keberadaan lembaga ini menurut ketentuan UUD 1945 pasca- 
perubahan dikritisi banyak kalangan.

Lembaga ini semula didesain sebagai kamar kedua parlemen Indonesia di masa depan. Akan tetapi, salah satu ciri bikameralisme yang dikenal di dunia ialah apabila kedua kamar yang dimaksud sama-sama menjalankan fungsi legislatif sebagaimana seharusnya. Padahal, jika diperhatikan, DPD sama sekali tidak mempunyai kekuasaan apapun di bidang ini. DPD hanya memberikan masukan, pertimbangan, usul, ataupun saran, sedangkan yang berhak memutuskan adalah DPR, sehingga DPD lebih tepat disebut sebagai Dewan Pertimbangan DPR, karena kedudukannya hanya memberikan pertimbangan kepada DPR.

\section{Sistem Pemerintahan Presidensial}

Kelebihan sistem presidensial pasca-amandemen UUD 1945 justru lebih menjamin stabilitas pemerintahan. Sistem ini juga dapat dipraktikkan dengan tetap menerapkan sistem multipartai yang dapat mengakomodasi peta konfigurasi kekuatan politik dalam masyarakat yang dilengkapi pengaturan konstitusional untuk mengurangi dampak negatif atau kelemahan bawaan dari sistem presidensial tersebut.

Dalam sistem pemerintahan presidensial, terdapat lima prinsip penting, yaitu:

a. Presiden dan Wakil Presiden dipilih oleh rakyat secara langsung dan karena itu secara politik tidak bertanggung jawab kepada Majelis Permusyawaratan Rakyat atau lembaga parlemen, melainkan bertanggung jawab langsung kepada rakyat yang memilihnya.

b. Presiden dan Wakil Presiden merupakan satu institusi penyelenggara kekuasaan eksekutif negara yang tertinggi di bawah Undang-Undang Dasar. Dalam sistem ini tidak dikenal dan tidak perlu dibedakan adanya kepala negara dan kepala pemerintahan. Keduanya adalah Presiden dan Wakil Presiden. Dalam menjalankan pemerintahan negara, kekuasaan, dan tanggung jawab politik berada di tangan Presiden (concentration of power and responsibility upon the President).

c. Presiden dan/atau Wakil Presiden dapat dimintakan pertanggungjawabannya secara hukum apabila Presiden dan/atau 
Wakil Presiden melakukan pelanggaran hukum konstitusi. Presiden atau Wakil Presiden dapat dituntut pertanggungjawaban oleh Dewan Perwakilan Rakyat untuk disidangkan dalam Majelis Permusyawaratan Rakyat, yaitu sidang gabungan antara Dewan Perwakilan Rakyat dan Dewan Perwakilan Daerah. Namun, sebelum diberhentikan, tuntutan pemberhentian Presiden dan/atau Wakil Presiden yang didasarkan atas tuduhan pelanggaran atau kesalahan, terlebih dulu harus dibuktikan secara hukum melalui proses peradilan di Mahkamah Konstitusi. Jika tuduhan bersalah itu dapat dibuktikan secara hukum oleh Mahkamah Konstitusi, barulah atas dasar itu, MPR bersidang dan secara resmi mengambil putusan pemberhentian.

d. Para Menteri adalah pembantu Presiden, Menteri diangkat dan diberhentikan oleh Presiden dan karena itu bertanggung jawab kepada Presiden, bukan dan tidak bertanggung jawab kepada parlemen. Kedudukannya tidak tergantung kepada parlemen. Di samping itu, para Menteri itulah yang pada hakikatnya merupakan para pemimpin pemerintahan dalam bidang masing-masing. Karena itu, kedudukannya sangat penting dalam menjalankan roda pemerintahan.

e. Untuk membatasi kekuasaan Presiden yang kedudukannya dalam sistem presidensial sangat kuat sesuai dengan kebutuhan untuk menjamin stabilitas pemerintahan, ditentukan pula bahwa masa jabatan Presiden lima tahunan tidak boleh dijabat oleh orang yang sama lebih dari dua kali masa jabatan.

f. Di samping itu, beberapa badan atau lembaga negara dalam lingkungan cabang kekuasaan eksekutif ditentukan pula independensinya dalam menjalankan tugas utamanya. Lembaga-lembaga eksekutif yang dimaksud adalah Bank Indonesia sebagai bank sentral, Kepolisian Negara, dan Kejaksaan Agung sebagai aparatur penegak hukum, dan Tentara Nasional Indonesia sebagai aparatur pertahanan negara. Pimpinan lembaga tersebut diangkat setelah mendapat persetujuan dari DPR. Sementara itu, presiden dapat memberhentikan pimpinan lembaga tersebut tanpa persetujuan DPR apabila terbukti secara hukum telah melakukan pelanggaran hukum. 
Kekuasaan Kehakiman Pasca

\section{Amandemen}

a. Mahkamah Agung

Sebelum adanya Perubahan UUD, kekuasaan kehakiman atau fungsi yudikatif (judicial) hanya terdiri atas badan-badan pengadilan yang berpuncak pada Mahkamah Agung. Lembaga Mahkamah Agung tersebut, sesuai dengan prinsip 'independent of judiciary' diakui bersifat mandiri dalam arti tidak boleh diintervensi atau dipengaruhi oleh cabang-cabang kekuasaan lainnya, terutama pemerintah.

Prinsip kemerdekaan hakim ini selain diatur dalam Undang-Undang Pokok Kekuasaan Kehakiman, juga tercantum dalam penjelasan Pasal 24 UUD 1945 yang menegaskan bahwa kekuasaan kehakiman tidak boleh dipengaruhi oleh cabang-cabang kekuasaan lain. Namun, setelah perubahan ketiga UUD 1945 disahkan, kekuasaan kehakiman negara kita mendapat tambahan satu jenis mahkamah lain yang berada di luar Mahkamah Agung yang mempunyai kedudukan setingkat atau sederajat dengan Mahkamah Agung. Lembaga tersebut adalah Mahkamah Konstitusi (constitutional court)

(Jimly

Asshiddiqie, 2003: 8).

b. Mahkamah Konstitusi

Dalam perubahan ketiga UndangUndang Dasar, Mahkamah Konstitusi ditentukan memiliki lima kewenangan, yaitu:

1) Melakukan pengujian atas konstitusionalitas Undang-Undang.

2) Mengambil putusan atau sengketa kewenangan antar lembaga negara yang ditentukan menurut UndangUndang Dasar.

3) Mengambil putusan atas pendapat Dewan Perwakilan Rakyat bahwa Presiden dan/atau Wakil Presiden telah melakukan pelanggaran hukum ataupun mengalami perubahan sehingga secara hukum tidak memenuhi syarat sebagai Presiden dan/atau Wakil Presiden menjadi terbukti dan karena itu dapat dijadikan alasan oleh Majelis Permusyawaratan Rakyat untuk memberhentikan Presiden dan/atau Wakil Presiden dari jabatannya.

4) Memutuskan perkara perselisihan mengenai hasil-hasil pemilihan umum.

5) Memutuskan perkara berkenaan dengan pembubaran partai politik. 
Mahkamah Konstitusi beranggotakan

9 orang yang memiliki integritas dan memenuhi persyaratan kenegarawanan, serta latar belakang pengetahuan yang mendalam mengenai masalah-masalah ketatanegaraan. Ketua dan Wakil Ketua Mahkamah Konstitusi dipilih dari dan oleh anggotanya sendiri yang berasal dari 3 orang yang dipilih oleh Dewan Perwakilan Rakyat, 3 orang yang ditentukan oleh Mahkamah Agung, dan 3 orang ditentukan oleh Presiden.

\section{c. Komisi Yudisial}

Meskipun lembaga baru ini tidak menjalankan kekuasaan kehakiman, tetapi keberadaannya diatur dalam UUD 1945 Bab IX tentang Kekuasaan Kehakiman. Karena itu, keberadaannya tidak dapat dipisahkan dari kekuasaan kehakiman. Dalam Pasal 24B ditegaskan:

(1) Komisi Yudisial bersifat mandiri yang berwenang mengusulkan pengangkatan Hakim Agung dan mempunyai kewenangan lain dalam rangka menjaga dan menegakkan kehormatan, keleluhuran martabat, serta perilaku hakim.

(2) Anggota Komisi Yudisial harus mempunyai pengetahuan dan pengalaman di bidang hukum serta memiliki integritas dan kepribadian yang tidak tercela.

(3) Anggota Komisi Yudisial diangkat dan diberhentikan oleh Presiden dengan persetujuan DPR.

(4) Susunan, kedudukan, dan keanggotaan Komisi Yudisial diatur dengan Undang-Undang.

Dari ketentuan mengenai Komisi Yudisial ini dapat dipahami bahwa jabatan hakim dalam konsepsi UUD 1945 dewasa ini adalah jabatan kehormatan yang perlu dijaga dan ditegakkan kehormatannya oleh suatu lembaga yang juga bersifat mandiri, yaitu Komisi Yudisial. Pembentukan lembaga baru ini dapat dikatakan merupakan pengembangan lebih lanjut terhadap pembentukan Majelis Kehormatan Hakim Agung yang sudah berkembang selama ini. Akan tetapi, jika majelis semacam ini dibentuk di lingkungan internal Mahkamah Agung, maka sulit diharapkan akan efektif menjalankan fungsi pengawasan atas kehormatan hakim agung itu sendiri, karena kedudukannya yang tidak independen terhadap subjek yang akan diawasi.

7. Badan Pemeriksa Keuangan 
Dalam perubahan amandemen ketiga UUD 1945, keberadaan badan pemeriksa ini mengalami perubahan yang sangat mendasar. Tugas BPK diantaranya :(1) Untuk memeriksa pengelolaan dan tanggung jawab tentang keuangan negara diadakan satu badan pemeriksa keuangan yang bebas dan mandiri; (2) Hasil pemeriksaan keuangan negara diserahkan kepada DPR, DPD, dan DPRD sesuai kewenangannya; (3) Hasil pemeriksaan tersebut ditindaklanjuti oleh lembaga perwakilan dan/atau badan sesuai dengan Undang-Undang." Walaupun hasil pemeriksaan keuangaan BPK diserahkan juga ke DPRD, tetapi BPK tidak mempunyai hubungan dengan DPRD, laporan yang diserahkan hanya terbatas pada laporan penggunaan Anggaran Pendapatan dan Belanja Negara (APBN) saja karena pelaksanaan APBN itu terdapat juga di daerah-daerah.

\section{Dari ketentuan-ketentuan} tersebut di atas, setidaknya ada dua perkembangan baru yang terjadi dengan Badan Pemeriksa Keuangan, yaitu menyangkut perubahan bentuk organisasi secara struktural dan menyangkut perluasan jangkauan tugas pemeriksaannya secara fungsional.
Sebelumnya, organisasi BPK hanya memiliki kantor perwakilan di beberapa provinsi saja karena kedudukan kelembagaannya memang hanya terkait dengan fungsi pengawasan oleh DPR RI terhadap kinerja pemerintahan di tingkat pusat saja.

\section{Daftar Pustaka}

Amos, Abraham. (2007). Sistem Ketatanegaraan Indonesia. Jakarta: Grafindo Persada. Maarif, Ahmad Syafii. (1985). Masalah Kenegaraan. Jakarta: LP3ES.

Maarif, Ahmad Syafii. (2002). Refleksi 50 Tahun Indonesia Merdeka. Yogyakarta: UNY.

Amin, SM. (1967). Indonesia di Bawah Rezim Demokrasi Terpimpin. Jakarta: Bulan Bintang.

Joeniarto. (1984). Sejarah Ketatanegaraan Republik Indonesia. Yogyakarta: Gadjah Mada Press.

J.D. Legge. (1993). Kaum Intelektual dan Perjuangan Kemerdekaan; Peranan Kelompok Sutan Sjahrir. terj. Hasan Basri. Jakarta: Pustaka Utama Grafiti.

Kahin, G.McT. (1963). Nationalism and Revolution in Indonesia. Ithaca, 
New York: Cornell University Press.

Leirisa, R.Z. (1986). Sejarah

Perekonomian Indonesia. Jakarta:

Depdikbud.

March Block. (1961). Social Society.

Chicago: University of Chicago.

Musa As'yari dalam Sarbini (2005).

Islam Tepian Revolusi; Idiologi Pemikiran dan gerakan. Yogyakarta: Pilar Media.

Rukiyati. (2008) Pendidikan Pancasila. Yogyakarta: UNY Press

Sartono Kartodirdjo. (1966). The Peasants, Revolt of Banten in 1888: Its Condition, Course and

dan Nugroho Notosusanto. (1990). Sejarah Nasional Indonesia VI. Jakarta : Balai Pustaka

Ricklef, M.C. (1993). Sejarah Indonesia Modern. Yogyakarta: Gadjah Mada University Press.

Wineburg. (2006). Berpikir Historis: Memetakan Masa Depan, Mengajarkan Masa Lalu, terj. Masri Maris, Jakarta: Yayasan Obor Indonesia.

Wawan Tunggul Alam (2003), Demi Bangsaku Pertentangan Sukarno Vs. Hatta, Jakarta: Gramedia Pustaka Utama.
Ihza Mahendra, dalam http//setneg.go.id,diakses tanggal 24 oktober 2011

\section{Tentang Penulis}

Zulkarnain, Dosen Jurusan Pendidikan Sejarah, Fakultas Ilmu Sosial Universitas Negeri Yogyakarta. Mata Kuliah Keahlian: Sejarah Tatanegara. 
